\title{
Phytoplankton in Boom Beach, Banyuwangi Regency East Java : Their Existence as a Bioindicator of Water Saprobity
}

\author{
Anisa Qurota Ayun, Nurwidodo, Husamah* \\ Pendidikan Biologi, Fakultas Keguruan dan Ilmu Pendidikan, Universitas Muhammadiyah Malang. Jl. Raya \\ Tlogomas No. 246 Malang 65144, Indonesia. \\ *Corresponding author: usya_bio@umm.ac.id
}

\begin{abstract}
Boom Beach is used as a tourist spot and a turtle breeding place The existence of a relatively dense residential area can provide the potential for waste entering the water area. This can cause a decrease in water quality. The presence of various wastes causes pollution in the coastal area of Boom Beach. The purpose of the study was to determine the probity index of the waters of Boom Beach, Banyuwangi Regency, East Java. This research method uses quantitative methods. The results showed that there were 24 phytoplankton species, the saprobic index value was between $0.000-1,200$ and the tropic saprobic index value was between $0.133-0.600$. Based on the average value of the saprobic index, which is 0.657 including -Mesosaprobic and classified as a lightly polluted category for the trophic value of the saprobic index of 0.384 indicating the $/ \alpha$-Mesosaprobic phase and classified as a moderately polluted category.
\end{abstract}

Keywords: bioindicator, boom beach, coastal, phytoplankton, saprobity

\section{ABSTRAK}

Pantai Boom dimanfaatkan sebagai tempat wisata dan tempat penangkaran penyu. Adanya pemukiman warga yang relative padat bisa memberikan potensi limbah yang memasuki area perairan. Limbah tersebut menyebabkan pencemaran pada area pesisir Pantai Boom. Tujuan dari penelitian untuk mengetahui indeks saprobitas perairan Pantai Boom Kabupaten Banyuwangi Provinsi Jawa Timur. Metode penelitian disini memakai metode kuantitatif. Hasil penelitian diperoleh fitoplankton yang ditemukan sebanyak 24 spesies, nilai saprobik indeks antara 0,000 - 1,200 dan nilai tropik saprobik indeks antara 0,133 - 0,600. Berdasarkan nilai rata-rata saprobik indeks yaitu 0,657 termasuk $\beta$ Mesosaprobik dan tergolong kategori tercemar ringan sedangkan untuk nilai tropik saprobik indeks sebesar 0,384 menunjukkan fase $\beta / \alpha$-Mesosaprobik dan tergolong kategori tercemar sedang.

Kata Kunci : bioindikator, fitoplankton, pantai boom, pesisir, saprobitas

\section{PENDAHULUAN}

Indonesia ialah suatu negara kepulauan apabila dilihat sesuai dengan letak astronomi, Indonesia berada di garis 60 LU - 110 LS serta 950 - 1410 BT sedangkan secara geografi
Indonesia berada diantara benua Asia, benua Australia diantara Samudra pasifik dan Samudra Hindia [1]. Indonesia mempunyai pantai yang menyebar dari Sabang hingga Merauke seperti Pantai Boom yang berada di Kabupaten Banyuwangi. 
Pantai boom suatu pantai yang berada di Kampung Mandar, terletak di Kecamatan Banyuwangi Kabupaten Banyuwangi Jawa Timur. Perairan Pantai Boom Kabupaten Banyuwangi Jawa Timur banyak dimanfaatkan sebagai tempat wisata, tempat penangkaran penyu dan berbagai organisme di darat maupun laut. Di sisi lain, adanya pemukiman warga yang relative padat bisa memberikan potensi limbah yang memasuki area perairan. Hal tersebut dapat menyebabkan penurunan kualitas perairannya. Adanya berbagai limbah tersebut menyebabkan pencemaran pada area pesisir Pantai Boom Kabupaten Banyuwangi yang berdampak buruk khusunya dalam organisme di perairan.

Fitoplankton mempunyai peran yang penting pada perairan serta mempunyai kontribusi sebagai pihak produktivitas primer yang bisa memberikan sumbangan energi untuk pihak konsumen tahap lanjut sehingga plankton dapat digunakan sebagai bioindikator kesuburan peraira. Jenis biota yang penting serta memiliki peran besar pada air ialah fitoplankton [2].

Fitoplankton termasuk indikator biologi yang bisa dijadikan sebagai parameter untuk melakukan evaluasi pada kualitas serta rahasia kesuburan sebuah perairan. Indeks saprobitas pada perairan dilakukan pengukuran memakai tipe fitoplankton yang didapatkan, sebab setiap tipe fitoplankton termasuk penyusun dari suatu kelompok proyek yang bisa memberikan pengaruh terhadap nilai saprobitas [3]. Salah satu metode yang dilakukan untuk melakukan pengukuran kualitas sebuah perairan yaitu dengan melihat nilai koefisien saprodiknya [4]. Koefisien saprobik merupakan dialog indeks yang berhubungan erat dengan rasio pencemaran, hal ini yang bisa memberikan indikasi terhadap rasio kualitas air di sebuah perairan [5].

Faktor yang menunjang tumbuhnya fitoplankton begitu komplek serta saling melakukan interaksi dari aspek fisika ataupun kimia perairan misalnya intensitas cahayanya, oksigen, temperatur serta keberadaan unsur hara nitrogen serta fosfor, sedangkan faktor biologinya ialah terdapat tindakan pemangsaan dari hewan, dekomposisi serta mortalitas alami [5]. Pendekatan faktor biologi merupakan suatu hal yang sangat bermanfaat, sebab organisme itu bisa melakukan refleksi keberadaan perubahan yang terjadi karena adanya penurunan kualitas sebuah perairan. Jumlah fitoplankton diberikan pengaruh oleh keadaan aspek fisika kimia air sebab keberadaan hal tersebut sangat dipengaruhi oleh keadaan perairan.

Fitoplankton memiliki peran yang begitu penting didalam melakukan penjagaan keseimbangan ekosistem air terutama ekosistem yang berada di laut di area Pantai Boom Kecamatan Mandar Kabupaten Banyuwangi, serta terdapat informasi yang kurang tentang bagaimana kelimpahan serta keberagaman fitoplankton, sehingga perlu dilakukan kajian dengan tujuan penelitian ini sebagai tambahan informasi mengenai kualitas perairan dilihat dari keberadaan komunitas dari fitoplankton.

\section{METODE}

\section{Metode, tempat dan waktu penelitian}

Metode yang dipakai metode kuantitatif dan dilakukan observasi secara langsung kelapangan untuk mengumpulkan data. Tempat penelitian terdapat 5 stasiun dengan ulangan sebanyak 3 kali jarak antar stasiun 200 meter sepanjang 1 $\mathrm{km}$ di perairan Pantai Boom Desa Kampung Mandar, Kecamatan Banyuwangi Jawa Timur. Penelitian dilakukan pada Agustus - Juli 2021.

\section{Pengambilan sampel fitoplankton}

Pengambilan sampel fitoplankton dilaksanakan dengan penyaringan menggunakan plankton net dan dimasukkan kebotol yang telah diberi larutan formalin dengan konsentrasi $4 \%$ dan lugol sebanyak 3 tetes dan akan diidentifikasi menggunakan SRCC (Sedwick Rafter Counting Cells) dan mikroskop di laboratorium Biologi. Pengukuran kondisi fisik dan kimia air yaitu temperatur, $\mathrm{pH}$, salinitas, DO dan kecerahan air. 


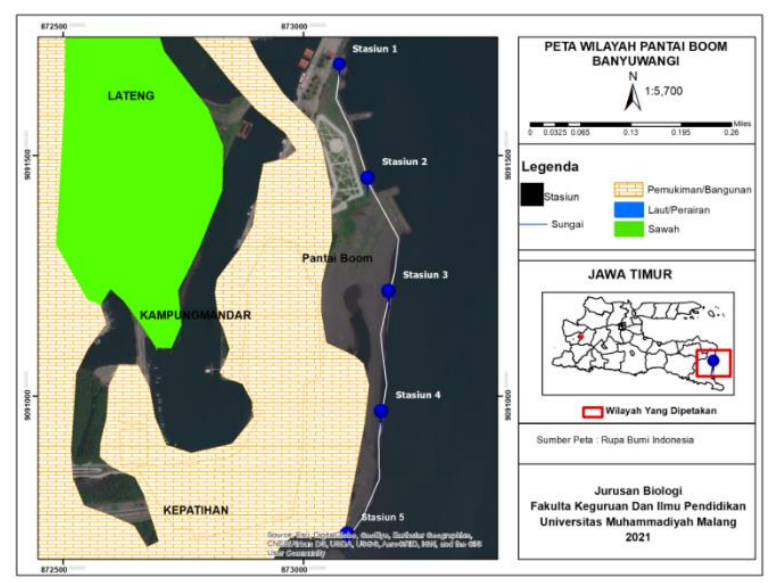

Gambar 1. Lokasi Penelitian

\section{HASIL}

\section{Jumlah dan jenis fitoplankton}

Hasil penelitian yang sudah dilaksanakan pada perairan Pantai Boom Banyuwangi. Berjumlah spesies fitoplankton yang didapatkan dengan banyak 24 spesies. Klasifikasi fitoplankton yang diperoleh disajikan pada Tabel 1.

Jenis fitoplankton yang banyak termasuk kedalam kelas saprobik B-Mesosaprobik sebanyak 14 spesies dengan total individu sebanyak 143 ind/L sedangkan jenis fitoplankton yang paling sedikit termasuk ke dalam kelas saprobik oligosaprobik sebanyak 2 spesies dengan total individu sebanyak 28 ind/L selain itu terdapat fitoplankton non saprobik sebanyak 1 spesies dengan total individu sebanyak 11 ind/L. Total individu yang ditemukan pada lokasi penelitian di 5 stasiun yaitu sebanyak 469 ind/L. Spesies yang banyak ditemui ialah Calothrix sp sebanyak 83 ind/L sedangkan spesies yang sedikit ditemui ialah Tetraspora, Navicula sp dan Tetraedron minimum masingmasing sebanyak 1 ind/L. Spesies fitoplankton yang ditemukan di 5 stasiun adalah Tetra edron triangulare sebanyak 11 ind/L dan Synedra ulna sebanyak 25 ind/L.

\section{Kelimpahan fitoplankton (N)}

Nilainya kelimpahan yang didapatkan atas penelitian yang sudah dilaksanakan diperoleh kelimpahan fitoplankton tertinggi didapati didalam stasiun 1 nilainya 10,951 ind/L. Sedangkan kelimpahan terendah didapati didalam stasiun 3 dengan nilai $6,531 \mathrm{ind} / \mathrm{L}$

Tabel 2. Kelimpahan fitoplankton

\begin{tabular}{cc}
\hline Stasiun & Kelimpahan Fitoplankton \\
\hline 1 & 10.951 \\
2 & 9.043 \\
3 & 6.531 \\
4 & 7.850 \\
5 & 9.514 \\
\hline Jumlah & 43.889 \\
\hline Rata-Rata & 8.778 \\
\hline
\end{tabular}

Indeks keanekaragaman fitoplankton $\left(\mathrm{H}^{\prime}\right)$

Tabel 3. Indeks keanekaragam fitoplankton ( $\left.\mathrm{H}^{\prime}\right)$

\begin{tabular}{lll}
\hline Stasiun & $\begin{array}{l}\text { Keanekaragaman } \\
\text { Fitoplankton }\end{array}$ & Kategori \\
\hline Stasiun 1 & 1.852 & Sedang \\
Stasiun 2 & 1.863 & Sedang \\
Stasiun 3 & 2.240 & Sedang \\
Stasiun 4 & 1.940 & Sedang \\
Stasiun 5 & 1.812 & Sedang \\
\hline Jumlah & 9.708 & \\
Rata-Rata & 1.942 & Sedang \\
\hline
\end{tabular}

Indeks Keanekaragaman (H') fitoplankton pada tiap stasiun terlihat bahwa nilainya indeks keanekaragaman $\left(\mathrm{H}^{\prime}\right)$ tertinggi terdapat pada stasiun 3 sebesar 2,240 dengan kategori sedang dan nilainya indeks aneragaman terendah terdapat pada stasiun 5 sebesar 1,812 dengan kategori sedang. Nilai keanekaragaman (H') yang didapatkan dari stasiun 1-5 ini berkisar antara 1,812-2,240 dan dikaitkan dengan Indeks Keanekaragaman Shannon-Wiener (Odum, 1994): yaitu nilai $1<\mathrm{H}^{\prime}<3$ yang artinya indeks keanekaragaman sedang. 
Tabel 1. Jumlah dan jenis fitoplankton yang dijumpai dipantai Boom Kabupaten Banyuwangi Jawa Timur

JENIS FITOPLANKTON

JUMLAH FITOPLANKTON

\begin{tabular}{|c|c|c|c|c|c|c|c|c|c|c|c|c|c|c|c|c|c|c|}
\hline \multirow[t]{2}{*}{ No } & \multirow{2}{*}{$\begin{array}{l}\text { Kelompok } \\
\text { Saprobik }\end{array}$} & \multirow{2}{*}{ Spesies } & \multicolumn{3}{|c|}{ Stasiun 1} & \multicolumn{3}{|c|}{ Stasiun 2} & \multicolumn{3}{|c|}{ Stasiun 3} & \multicolumn{3}{|c|}{ Stasiun 4} & \multicolumn{3}{|c|}{ Stasiun 5} & \multirow[t]{2}{*}{ Jumlah } \\
\hline & & & U1 & U2 & U3 & U1 & U2 & U3 & U1 & U2 & U3 & U1 & U2 & U3 & U1 & U2 & U3 & \\
\hline 1 & \multirow{4}{*}{$\begin{array}{l}\text { Poli } \\
\text { saprobic }\end{array}$} & Calothrix sp & 9 & 7 & 11 & 9 & 16 & 7 & 4 & 7 & 13 & - & - & - & - & - & - & 83 \\
\hline 2 & & Lyngbya $\mathrm{sp}$ & - & - & - & 4 & 2 & 1 & 2 & 0 & 1 & - & - & - & - & - & - & 10 \\
\hline 3 & & $\begin{array}{l}\text { Aphanizomenon } \\
\text { flosaquae }\end{array}$ & - & - & - & - & - & - & - & - & - & 8 & 5 & 13 & - & - & - & 26 \\
\hline 4 & & Oscilatoria tenuis & - & - & - & - & - & - & - & - & - & 0 & 2 & 5 & - & - & - & 7 \\
\hline 5 & \multirow{3}{*}{$\begin{array}{l}\text { a-Meso } \\
\text { saprobic }\end{array}$} & Crytomonad & 3 & 6 & 4 & 7 & 5 & 8 & 0 & 3 & 2 & - & - & - & 5 & 8 & 16 & 67 \\
\hline 6 & & $\begin{array}{l}\text { Uronema } \\
\text { elongatum } \\
\text { Hodgetts }\end{array}$ & 4 & 5 & 3 & 3 & 6 & 2 & 7 & 8 & 11 & - & - & - & 4 & 5 & 8 & 66 \\
\hline 7 & & Euglena viridis & 7 & 5 & 4 & 1 & 0 & 2 & 0 & 2 & 0 & - & - & - & 2 & 1 & 4 & 28 \\
\hline 8 & \multirow{14}{*}{$\begin{array}{l}\text { B-Meso } \\
\text { saprobic }\end{array}$} & $\begin{array}{l}\text { Tetra edron } \\
\text { triangulare }\end{array}$ & 2 & 0 & 1 & 0 & 0 & 2 & 0 & 1 & 0 & 1 & 0 & 3 & 0 & 0 & 1 & 11 \\
\hline 9 & & Synedra ulna & 1 & 0 & 2 & 3 & 0 & 1 & 0 & 4 & 3 & 1 & 0 & 2 & 1 & 2 & 5 & 25 \\
\hline 10 & & $\begin{array}{l}\text { Tetra plektron } \\
\text { torsum }\end{array}$ & 8 & 2 & 5 & 1 & 0 & 1 & 0 & 2 & 1 & - & - & - & 0 & 2 & 6 & 28 \\
\hline 11 & & $\begin{array}{l}\text { Straura strums } \\
\text { mithii }\end{array}$ & - & - & - & - & - & - & 0 & 3 & 2 & - & - & - & - & - & - & 5 \\
\hline 12 & & $\begin{array}{l}\text { Tetraedron } \\
\text { minimum }\end{array}$ & - & - & - & - & - & - & 0 & 0 & 1 & - & - & - & - & - & - & 1 \\
\hline 13 & & Navicula sp & - & - & - & - & - & - & 0 & 0 & 1 & - & - & - & - & - & - & 1 \\
\hline 14 & & Fragillaria sp & - & - & - & - & - & - & 2 & 5 & 4 & 0 & 1 & 4 & - & - & - & 16 \\
\hline 15 & & $\begin{array}{l}\text { Rosenvingiella } \\
\text { radicans }\end{array}$ & - & - & - & - & - & - & 0 & 2 & 5 & - & - & - & - & - & - & 7 \\
\hline 16 & & Tribonemaviride & - & - & - & - & - & - & - & - & - & 2 & 0 & 7 & - & - & - & 9 \\
\hline 17 & & Micrasterias & - & - & - & - & - & - & - & - & - & 2 & 1 & 4 & - & - & - & 7 \\
\hline 18 & & $\begin{array}{l}\text { Sphaerolea } \\
\text { soleirolii }\end{array}$ & - & - & - & - & - & - & - & - & - & 0 & 0 & 3 & - & - & - & 3 \\
\hline 19 & & Spirogyra sp & - & - & - & - & - & - & - & - & - & - & - & - & 6 & 9 & 12 & 27 \\
\hline 20 & & Tetraspora & - & - & - & - & - & - & - & - & - & - & - & - & 0 & 0 & 1 & 1 \\
\hline 21 & & $\begin{array}{l}\text { Bracchio goniumo } \\
\text { phiaster }\end{array}$ & - & - & - & - & - & - & - & - & - & - & - & - & 0 & 0 & 2 & 2 \\
\hline 22 & \multirow{2}{*}{$\begin{array}{l}\text { Oligo } \\
\text { saprobic }\end{array}$} & $\begin{array}{l}\text { Skeletonema } \\
\text { costatum }\end{array}$ & 1 & 0 & 3 & 6 & 4 & 4 & 2 & 0 & 3 & - & - & - & - & - & - & 23 \\
\hline 23 & & Ulotrhrix sp & - & - & - & 0 & 0 & 1 & 1 & 0 & 2 & - & - & - & 0 & 0 & 1 & 5 \\
\hline 24 & $\begin{array}{l}\text { Non } \\
\text { Saprobik }\end{array}$ & $\begin{array}{l}\text { Lingulo dinium } \\
\text { polyedrum }\end{array}$ & - & - & - & - & - & - & - & - & - & 0 & 3 & 8 & - & - & - & 11 \\
\hline & Jumlah & & 35 & 25 & 33 & 34 & 33 & 29 & 18 & 37 & 49 & 14 & 12 & 49 & 18 & 27 & 56 & 469 \\
\hline
\end{tabular}


Indeks Keseragaman (E)

Tabel 4. Nilai Indeks Keseragaman (E)

\begin{tabular}{lll}
\hline & $\begin{array}{l}\text { Indeks } \\
\text { Keseragaman } \\
\text { Fitoplankton }\end{array}$ & Kategori \\
\hline Stasiun & 0.891 & Tinggi \\
Stasiun 2 & 0.809 & Tinggi \\
Stasiun 3 & 0.827 & Tinggi \\
Stasiun 4 & 0.883 & Tinggi \\
Stasiun 5 & 0.787 & Tinggi \\
\hline Jumlah & 4.197 & \\
Rata-Rata & 0.839 & Tinggi \\
\hline
\end{tabular}

Nilai keseragaman (E) fitoplankton yang didapat dari stasiun 1 , stasiun 2, stasiun 3, stasiun 4 dan stasiun 5 berkisar antara 0,7870,891. Keseragaman pada setiap stasiun mempunyai nilai yang tidaklah berbeda jauh dimana keseragaman didalam setiap stasiun digolongkan kategori keseragaman tinggi. Keseragaman tertinggi terjadi kepada stasiun 1 dengan nilainya sebesar 0,891 dengan kategori keseragaman tinggi sedangkan nilai keseragaman terendah terjadi didalam stasiun 5 atas nilai 0,787 dengan kategori keseragaman tinggi.

Indeks dominansi (ID)

Tabel 5. Indeks dominansi (ID)

\begin{tabular}{ccc}
\hline Stasiun & Indeks Dominasi & Kategori \\
\hline Stasiun 1 & 0.023 & Rendah \\
Stasiun 2 & 0.020 & Rendah \\
Stasiun 3 & 0.010 & Rendah \\
Stasiun 4 & 0.020 & Rendah \\
Stasiun 5 & 0.020 & Rendah \\
\hline Jumlah & 0.093 & \\
Rata-Rata & 0.019 & Rendah \\
\hline
\end{tabular}

Nilai rata-rata indeks dominansi yang didapatkan atas stasiun 1 sampai dengan stasiun 5 yaitu 0,019 berkisar antara $0,010-0,23$. Indeks dominansi paling tinggi didapati didalam stasiun 1 dengan nilai sebesar 0,023 dengan kategori dominansi rendah dan nilai indeks dominansi terendah didapatkan didalam stasiun 3 sebesar 0,010 dengan kategori dominansi rendah. Berdasarkan nilai rata-rata indeks dominansi kelima stasiun penelitian didapatkan bahwa seluruh stasiun penelitian tergolong kedalam kategori dominansi rendah.

Saprobik indeks dan tropik saprobik indeks Tabel 6. Nilai indeks saprobik

\begin{tabular}{ccc}
\hline Stasiun & $\begin{array}{c}\text { Saprobitas } \\
\text { Indeks }\end{array}$ & Kategori \\
\hline Stasiun 1 & 0,750 & Ringan \\
Stasiun 2 & 0,600 & Ringan \\
Stasiun 3 & 0,733 & Ringan \\
Stasiun 4 & 0,000 & Sedang \\
Stasiun 5 & 1,200 & Ringan \\
\hline Jumlah & 3,283 & \\
Rata-Rata & 0,657 & Ringan \\
\hline
\end{tabular}

Nilai Indeks Saprobik (SI) fitoplankton yang didapat dari stasiun 1, stasiun 2, stasiun 3, stasiun 4 dan stasiun 5 berkisar antara 0,000 1,200 . Nilai rata-rata indeks saprobik yang di dapat dari stasiun 1 sampai stasiun 5 yaitu 0,657, nilainya disini memperlihatkan bahwa fase saprobik berlokasi penelitian ialah $\beta$ Mesosaprobik dan tergolong kategori tercemar ringan.

Tabel 7. Nilai Tropik Saprobitas Indeks (TSI)

\begin{tabular}{lll}
\hline Stasiun & $\begin{array}{l}\text { Tingkat } \\
\text { Saprobitas Indeks }\end{array}$ & Kategori \\
\hline Stasiun 1 & 0,479 & Rendah \\
Stasiun 2 & 0,133 & Rendah \\
Stasiun 3 & 0,563 & Rendah \\
Stasiun 4 & 0,143 & Rendah \\
Stasiun 5 & 0,600 & Rendah \\
\hline
\end{tabular}

Nilai Tropik Saprobik Indeks (TSI) fitoplankton yang didapat dari stasiun 1 , stasiun 2, stasiun 3, stasiun 4 dan stasiun 5 berkisar antara $0,133-0,600$. Nilai rata-rata Tropik Saprobik Indeks (TSI) yang di dapat dari stasiun 1 sampai stasiun 5 yaitu 0,384 , nilainya disini memperlihatkan bahwa fase saprobik berlokasi penelitian ialah $\beta / \alpha$-Mesosaprobik dan tergolong kategori tercemar sedang.

\section{Faktor fisik dan kimia perairan}

Suhu perairan yang didapat dari stasiun 1, 2, 3,4 dan 5 berkisar antara $26^{\circ} \mathrm{C}-28^{\circ} \mathrm{C}$. Suhu didalam tiap stasiun mempunyai nilai yang tidak berbeda jauh. Suhu paling tinggi didapati stasiun 5 sebesar $28^{\circ} \mathrm{C}$ sedangkan tempererature 
terendah didapati didalam stasiun 2 yaitu $26^{\circ} \mathrm{C}$, rata-rata temperature 5 stasiun pada lokasi penelitian yaitu sebesar $27^{\circ} \mathrm{C}$. Nilai $\mathrm{pH}$ perairan yang didapat dari stasiun $1,2,3,4$ dan 5 berkisar antara 5,4-7,5. Nilai $\mathrm{pH}$ didalam tiap stasiun mempunyai nilai yang tidak berbeda jauh. Derajat keasaman tertinggi didapati didalam stasiun 3 dan stasiun 5 yaitu 7,5 sedangkan $\mathrm{pH}$ terendah didapati didalam stasiun 1 yaitu 5,4, rata-rata $\mathrm{pH}$ pada 5 stasiun di lokasi penelitian yaitu sebesar 6,6.

Nilai Dissolved Oxygen (DO) perairan yang didapat dari stasiun $1,2,3,4$ dan stasiun 5 berkisar antara 4,90 mg/L- 5,47 mg/L. Nilai DO tiap stasiun mempunyai nilai yang tidak berbeda jauh. Nilai Dissolved Oxygen (DO) tertinggi didapati didalam stasiun 3 yaitu 5,47 $\mathrm{mg} / \mathrm{L}$ sedangkan DO terendah didapati stasiun 5 yaitu $4,90 \mathrm{mg} / \mathrm{L}$, rata-rata DO pada 5 stasiun di lokasi penelitian yaitu sebesar 5,21 mg/L.

Nilai salinitas perairan yang didapat dari stasiun 1, 2, 3, 4 dan stasiun 5 yaitu sebesar $32 \%$. Nilainya salinitas didalam tiap stasiun mempunyai nilai yang sama. Nilai kecerahan perairan yang didapat dari stasiun $1,2,3$, stasiun 4 dan stasiun 5 berkisar antara $5 \mathrm{~cm}-35 \mathrm{~cm}$. Nilainya kecerahan didalam tiap stasiun mempunyai nilai yang tidaklah berbeda jauh. Nilainya kecerahan paling tinggi didapati pada stasiun 3 yaitu $35 \mathrm{~cm}$ sedangkan kecerahan terendah didapati didalam stasiun 5 yaitu $5 \mathrm{~cm}$, rata-rata kecerahan pada 5 stasiun di lokasi penelitian yaitu sebesar $22 \mathrm{~cm}$.

Tabel 8. Nilai parameter fisik beserta kimia perairan

\begin{tabular}{cccccc}
\hline Stasiun & Suhu $\left({ }^{\mathbf{0}} \mathbf{C}\right)$ & $\mathbf{p H}$ & DO $(\mathbf{m g} / \mathbf{L})$ & Salinitas $\mathbf{( \% o})$ & Kecerahan $(\mathbf{c m})$ \\
\hline 1 & 27 & 5,4 & 5,17 & 32 & 30 \\
2 & 26 & 5,5 & 5,30 & 32 & 15 \\
3 & 27 & 7,5 & 5,47 & 32 & 35 \\
4 & 27 & 6,4 & 5,23 & 32 & 25 \\
5 & 28 & 7,5 & 4,90 & 32 & 5 \\
\hline Jumlah & 135 & 32,3 & 26,07 & 160 & 110 \\
Rata-Rata & 27 & 6,6 & 5,21 & 32 & 22 \\
\hline
\end{tabular}

\section{PEMBAHASAN}

\section{Jenis fitoplankton dan peranaannya}

Spesies terbanyak yang ditemukan di pantai Boom Kabupaten Banyuwangi Jawa Timur berasal dari kelompok saprobik $\beta$-mesosaprobik sebanyak 14 spesies yaitu Tetra edron triangulare, Synedra ulna, Tetra plektron torsum, Straura strums mithii, Tetraedron minimum, Navicula sp, Fragillaria sp, Rosenvingiella radicans, Tribonemaviride, Micrasterias, Sphaerolea soleirolii, Spirogyra sp, Tetraspora, Bracchio goniumo phiaster. Kelompok $\beta$-mesosaprobik tersusun dari Chlorococcales dan Bacillariophyceae. Banyaknya Chlorococcales dan Diantome /Bacillariophyceae yang ditemui pada kelas itu sebab jenis fitoplankton itu mempunyai toleransi yang begitu tinggi sehingga bisa dipakai untuk bioindikator mutu sir suatu perairan. Hal disini sesuai dengan penelitian Kamilah et al. (2014) [6] yang menyatakan bahwa plankton yang umumnya dipakai untuk bioindikator yaitu atas kelas Cyanophyceae dan kelas Bacillariophyceae. Kelas fitoplankton Bacillariophyceae mempunyai system adaptasi yang cukup bagus hal ini sesuai atas pernyataan yang menyatakan kelas fitoplankton Bacillariophyceae yaitu kelas atas komposisi paling tinggi, artinya kelas disini bisa mempertahankan hidupnya dan berkembang biak diri menjadikan berlimpah walaupun terjadi perubahan faktor lingkungan selain disitu menjelaskan bahwa diatom (Bacillariophyceae) yaitu jenis atas golongan fitoplankton yang biasa ditemui dilaut. Banyaknya kelas diatom diperairan penyebabnya dari kemampun untuk adaptasi dengan lingkungannya, sifatnyakosmopolit (tersebar dengan luas disemua perairan), tahan terhadap kondisi ekstrim beserta memiliki daya reproduksi yang tinggi [8].

Spesies tersedikit yang ditemukan di pantai Boom Kabupaten Banyuwangi Jawa Timur 
berasal dari kelompok saprobik oligosaprobik sebanyak 2 spesies yaitu Skeletonema costatum dan Ulotrhrix sp, 2 spesies tersebut dijadikan sebagai indikator pencemaran tingkat sedang [7]. Tiap jumlahnya dan jenisnya individu plankton yang ditemui akan berpengaruh pada tingkatan atas masing-masing kelompok saprobitas, sebab tiap individu akan memberikan tambahan nilai atas kelompok saprobik itu. Atas jumlah beserta jenis plankton yang dilihat bisa terkelompokan didalam berbagai kelompok saprobitas.

\section{Kelimpahan Fitoplankton (N)}

Sesuai hasil penelitian yang dilaksanakan terhadap fitoplankton dipantai Boom Kabupaten Banyuwangi Jawa Timur, diperoleh stasiun yang kelimpahannya paling tinggi ialah stasiun 1 sebesar 10,951 ind/L. Kelimpahan stasiun 1 yang tinggi diduga karena perairan kaya akan nutrisi dan bahan organik. Fitoplankton berkembang pada daerah yang cukup kaya akan bahan-bahan organik dan nutrisi. Tingggi nilai kelimpahan plankton disebabkan masuknya bahan organik pada perairan [8]. Stasiun yang kelimpahannya terendah yaitu stasiun 3 sebanyak 6,531 ind/L, hal disini didugai sebab pengaruh atas kandungan nutrisi yang rendah sehingga kelimpahan fitoplankton di stasiun 3 menjadi rendah karena fitoplankton tidak dapat berkembang biak jika nutrisi pada perairan tidak baik tingginya nutrient di perairan akan mempengaruhi tingginya kelimpahan fitoplankton [9]. Kelimpahan fitoplankton yang tinggi sangatlah dipengaruhi didalam ketersediaan nutrien/unsur hara didalam perairan yang juga tinggi [10].

Spesies yang mempunyai nilai kelimpahan (N) tertinggi ialah Calothrix sp sebesar 78,19 sel/L, hal disini penyebabnya karena kondisi lingkungan seperti fisik dan kimia yang sesuai untuk pertumbuhannya. Spesies disini ditemui didalam stasiun 1, 2 dan 3. Pantai Boom Kabupaten Banyuwangi Jawa Timur merupakan pantai yang banyak melakukan aktivitas sehinggga dengan langsung banyaknya nutrient yang masuk menuju perairan disebabkan aktivitas masyarakat, sehingga memberi dukungan perkembangan spesies itu.

Spesies yang memiliki nilai kelimpahan (N) terendah adalah Tetraspora, Navicula sp dan
Tetraedron minimum masing-masing sebanyak 1 ind/L, hal disini disebabkan sebab kondisi lingkungan contohnya fisik dan kimia yang kurang cocok untuk pertumbuhannya, kurang tersedianya nutrient dapat mempengaruhi kelimpahan fitoplankton di suatu perairan.

\section{Indeks Keanekaragaman (H')}

Berdasarkan hasil penelitian diketahui bahwa keanekaragaman didalam stasiun 1, 2, 3, 4 dan stasiun 5 tergolong didalam kategori keanekaragaman sedang dengan nilai dari 1,8122,240 dan memiliki nilai rata rata sebesar 1,942. Hal ini dapat mengindikasikan bahwa kondisi perairan di Pantai Boom Kabupaten Banyuwangi Jawa Timur sudah tercemar ringan hal ini sesuai dengan pernyataan Lee at al. (1978) yang menyatakan bahwa indeks keanekeragaman plankton <2,0 memperlihatkan kondisi perairan tercemar ringan. Nilainya indeks keanekaragaman ( $\left.\mathrm{H}^{\prime}\right)$ paling tinggi didapati didalam stasiun 3 yaitu 2,240 dengan kategori sedang dan nilai indeks keanekaragaman terendah terdapat didalam stasiun 5 sebesar 1,812 dengan kategori sedang hal ini disebabkan karena adanya genus yang mendominasi.

\section{Indeks Keseragaman (E)}

Berdasarkan hasil penelitian diketahui bahwa nilai indeks keseragaman tertinggi terdapat didalam stasiun 1 dengan nilainya 0,891 dengan kategori keseragaman tinggi sedangkan nilai terendah terdapat didalam stasiun 5 yaitu sebesar 0,787 dengan kategori keseragaman tinggi. Menurut Krebs (1985), keseragaman suatu populasi berkisar $0,6-1,0$ artinya keseragaman jenisnya tinggi. Jadi bisa tersimpulkan bahwa fitoplankton Pantai Boom Kabupaten Banyuwangi Jawa Timur mempunyai nilai Keseragaman Jenis yang tinggi, sehingga keseragaman individu relatif seragam ataupun jumlahnya individu masing-masing spesies relatif sama. Nilainya indeks keseragaman yang tinggi tergambar hampir rata dari jumlahnya individu didalam tiap spesies sebaliknya apabila indeks diversitas yang rendah memperlihatkan komunitas terdominasi dari satu ataupun sejumlah kecil spesies dengan kelimpahan tinggi. Tingginya nilai indeks keseragaman pada semua stasiun penelitian diperngaruhi dari kelimpahan fitoplankton yang rata, sehingga 
tidaklah terdapat spesies yang lebih mendominasi didalam perairan. Hal disini sesuai dengan [11] yang ternyatakan bahwa kian tinggi nilai indeks keseragaman ataupun mendekati nol memperlihatkan kian tinggi juga keseragaman populasi fitoplankton, berarti penyebaran jumlahnya individu tiap spesies sama dan kecenderungan tidak terdapat spesies tertentu yang mendominasi populasi itu.

\section{Indeks dominansi (ID)}

Berdasarkan hasil penelitian diketahui bahwa seluruh stasiun digolongkan didalam kategori dominansi rendah dengan nilai yang kisaran 0,010-0,023. Nilai indeks dominansi antara seluruh stasiun mempunyai nilai yang tidaklah berbeda jauh dimana nilainya ketiga stasiun masih dalam kisaran yang sama. Indeks dominansi fitoplankton (ID) tergambarkan terdapat ataupun tidak biota perairan yang mendominasi. Nilai indeks dominansi yang mendekati 1 jadi ada salah satunya jenis yang mendominasi dibanding jenis lainnya, hal disini disebabkan komunitas fitoplankton terjadi tekanan ekologis [11]. Berdasarkan hasil penelitian kisaran nilainya indeks dominansi mendekati 0,1 itu artinya tidak ada jenis fitoplankton yang mendominasi dalam semua stasiun.

\section{Saprobik Indeks (SI) dan Tingkat Saprobik Indeks (TSI)}

Sesuai hasil penelitian didapatkan nilainya dari saprobik indeks yang diperoleh didalam penelitian dari 5 stasiun 0,657. Nilainya disini memperlihatkan bahwa fase saprobik di Pantai Boom Kabupaten Banyuwangi Jawa Timur adalah $\beta$-Mesosaprobik. Fase $\beta$-Mesosaprobik adalah perairan yang tergolong kategori tercemar ringan sesuai dengan kriteria [12] nilai SI $\quad 0,5-1,0$ tergolong fase saprobik $\beta$ Mesosaprobik yaitu tingkat pencemaran ringan dengan bahan pencemar adalah bahan organik dan anorganik.

Berdasarkan hasil penelitian didapatkan nilai atas tingkat saprobik indeks yang didapatkan didalam penelitian yaitu 0,384 nilainya disini memperlihatkan bahwa fase saprobik pada tempat penelitian ialah $\beta / \alpha$-Mesosaprobik dan tergolong kategori tercemar sedang sesuai dengan kriteria menurut Suwondo et al. [13] dimana $0,0-0,5$ tergolong fase saprobik $\beta / \alpha-$ Mesosaprobik yaitu tingkat pencemaran sedang dengan bahan pencemar adalah bahan organic dan anorganic. Nilai tingkat saprobik indeks tertinggi terdapat ada stasiun 5 sebesar 0,600 tergolong kategori tercemar ringan sedangkan nilai tingkat saprobik indeks terendah berada pada stasiun 2 yaitu 0,133 tergolong kategori tercemar sedang.

Nilai SI dan TSI yang tergolong kategori tercemar ringan dikarenakan tersedianya bahan organic dan anorganik pada Pantai Boom Kabupaten Banyuwangi Jawa Timur yang disebabkan oleh banyak kegiatan yang dilakukan oleh masyarakat sekitar tempat penelitian yang menyebabkan banyaknya limbah domestic maupun limbah industri yang masuk pada badan perairan. Banyaknya masukan dari limbahlimbah tersebut menyebabkan kandungan unsur hara pada perairan menjadi tinggi dan melebihi ambang batas. Hal disini sesuai atas pernyataan Amin (2012) [14] yang menyatakan bahwa apabila bahan organik melebihi ambang batas wajar jadi kedudukan bahan organik itu dianggap sebagai bahan pencemar.

\section{Faktor Fisika dan Kimia Perairan Faktor Fisika Perairan}

Rata-rata suhu pada 5 stasiun di lokasi penelitian yaitu sebesar $27^{\circ} \mathrm{C}$. Kisaran suhu pada semua stasiun penelitian tergolong optimum untuk pertumbuhan fitoplankton, hal disini sesuai atas pernyataan Yazwar (2008) [15] yang dinyatakan bersuhu berpengaruh secara langsung langsung kepada berkembangnya dan bertumbuhnya fitoplankton yang mana bersuhu yang optimum mendukung bertumbuhnya plankton ialah antara $20-30^{\circ} \mathrm{C}$.

Nilainya kecerahan dari masing-masing stasiun di Pantai Boom Kabupaten Banyuwangi Jawa Timur berkisar 5-35 cm. Rendahnya penetrasi cahaya pada stasiun 5 penyebabnya sebab banyaknya aktivitas masyarakat yang mengakibatkan terdapatnya masukan zat terlarut ke badan perairan conothnya buangan atas limbah domestik yang didapati pada stasiun ini hal disini sesuai atas pernyataan Rasjid (2016) [16] yang ternyatakan bahwa kecerahan air yaitu salah satunya faktor yang berpengaruh didalam perairan, kecerahan sangatlah tertentukan dari adaya benda halus yang tersuspensi. Kian 
dalamnya cahaya yang menembus air artinya kian tinggi kemampuan organisme melaksanakan fotosintesis, jadi kian subur perairan itu beserta biota laut kian berkembangnya dengan bagus.

\section{Faktor Kimia Perairan}

Nilai derajat keasaman $(\mathrm{pH})$ pada tempat penelitian yaitu kisaran dari 5,4-7,5. Kisaran $\mathrm{pH}$ didalam semua stasiun masih tergolong optimal untuk pertumbuhan fitoplankton. $\mathrm{pH}$ yang optimal menurut Pulungan et al. (2020) [17] untuk bertumbuhnya fitoplankton kisaran dari 6,0-8,0 dan untuk zooplankton kisaran dari 5,08,0 . Sesuai nilai itu jadi Pantai Boom Kabupaten Banyuwangi Jawa Timur mempunyai $\mathrm{pH}$ yang normal dan masih mendukung untuk bertumbuhnya fitoplankton.

Nilai Dissolved Oxygen (DO) didalam perairan merupakan faktor penting untuk pengaturan metabolisme tubuh organisme untuk tumbuh beserta berkembang biak. Sesuai hasil penelitian diperoleh nilai Dissolved Oxygen (DO) di Pantai Boom Kabupaten Banyuwangi Jawa Timur berkisar 4,90-5,47 mg/l. Nilai oksigen terlarut pada stasiun 5 tergolong rendah namun nilainya oksigen terlarut disini masihlah didalam kisaran optimum untuk kehidupan plankton sesuai dengan baku mutu menurut KEPMEN-LH NO 115 Tahun 2003 batas minimal kandungan DO untuk peruntukan golongan $\mathrm{C}$ adalah $>3$. Rendahnya oksigen terlarut didalam stasiun 5 penyebabnya terdapat masukan senyawa organik dan anorganik yang berasal dari aktivitas masyarakat sehingga kebutuhan oksigen untuk mengurai senyawa itu yang menyebabkan minimnya oksigen terlarut di stasiun tersebut. Stasiun 1, 2, 3 dan stasiun 4 di lokasi pengamatan memiliki nilai kandungan DO yang bisa ditolerir dari organisme akuatik utamanya fitoplankton ialah tidaklah kurang atas $5 \mathrm{mg} / \mathrm{L}$ (Boyd, 1982) sedangkan stasiun 5 mempunyai nilai DO kurang atas $5 \mathrm{mg} / \mathrm{l}$ yaitu 4,90 mg/l namun menurut PP No 82 Tahun 2001, batas minimal kandungan DO untuk kategori kelas III (perikanan) ialah $4 \mathrm{mg} / \mathrm{L}$ maka dari itu dapat disimpulkan bahwa semua stasiun di lokasi penelitian masih memiliki nilai kandungan DO yang optimal untuk kehidupan fitoplankton.
Nilai salinitas stasiun 1, 2, 3, 4 dan stasiun 5 di Pantai Boom Kabupaten Banyuwangi Jawa Timur yaitu sebesar 32\%, tinggi salinitas bisa menjadi hambatan bertumbuhnya fitoplankton sebab menurut Gurning et al. (2020) [18] tingkat bertumbuhnya fitoplankton lebih tinggi pada perairan dengan salinitas yang rendah sehingga biomassa fitoplankton kecenderungan tinggi didalam perairan bersalinitas rendah. Menurut Nontji (2008), bahwa salinitas diperairan laut kisaran dari $24 \%-35 \%$. Sebaran salinitas dilaut terpengaruhi dari bermacam faktor contohnya faktor seperti sikrkulasi air, penguapan, curah hujan dan aliran sungai. Salinitas memberikan pengaruh terhadap kehidupan plankton di laut. Variasi salinitas berpengaruh kepada laju fotosintesis utamanya pada area esturasi terkhusus didalam fitoplankton yang dapat bertahan didalam batas-batas salinitas yang rendah [19].

\section{Hubungan Kelimpahan dan Keanekaragaman Fitoplankton dengan Saprobik Indeks}

Kesuburan perairan bisa terindikasikan dengan kelimpahan fitoplankton yang ada. Perubahan kepada mutu perairan bisa tertinjau atas kelimpahan dan komposisi Fitoplankton. Keberadaannya fitoplankton pada suatu perairan bisa memberi informasi terkait kondisi perairan dengan Indeks Saprobik [20].

Berdasarkan hasil penelitian diketahui bahwa hubungan antara kelimpahan fitoplankton dengan indeks saprobik dari Pearson Correlation sebesar 0,355 artinya bahwa ada hubungan antara kelimpahan fitoplankton dengan indeks saprobik sehingga koefisien determasi dari nilai kelimpahan fitoplankton dengan indeks saprobik adalah $12,6 \%$ sehingga jika kelimpahan fitoplankton bertambah maka nilai indeks saprobik juga akan meningkat, hal disini berkaitan atas nilai kelimpahan yang tidak tergolong didalam kelimpahan yang tinggi. Perbedaan jumlahnya organisme plankton didalam suatu perairan akan berpengaruh pada tingkatan saprobitas pada perairan itu. Nilai saprobitas perairan ialah gambaran atas tingkatan pencemaran perairan.

Hubungan antara keanekaragaman fitoplankton dengan indeks saprobik dari Pearson Correlation sebesar $-0,169$ artinya 
bahwa ada hubungan antara keanekargaman fitoplankton dengan indeks saprobik sehingga koefisien determasi dari nilai keanekargaman fitoplankton dengan indeks saprobik adalah $2,9 \%$ sehingga jika keanekaragaman fitoplankton bertambah maka nilai indeks saprobik juga akan meningkat hal ini disebabkan karena nilai indeks keanekaragaman yang termasuk kategori sedang. Nilai hubungan antara keanekaragaman fitoplankton dengan indeks saprobik lebih kecil dibandingkan dengan nilai hubungan antara kelimpahan fitoplankton dengan indeks saprobik hal ini dikarenakan nilai indeks keanekargaman yang lebih rendah dibandingkan nilai kelimpahan fitoplankton.

\section{KESIMPULAN}

Status kualitas air di Pantai Boom Kabupaten Banyuwangi Jawa Timur berdasarkan saprobik indeks (SI) yaitu sebesar 0,657 sehingga termasuk pada kelompok $\beta$-Mesosaprobik yang tergolong kategori tercemar ringan dengan bahan pencemar bahan organic dan bahan anorganik. Faktor fisika dan kimia di Pantai Boom Kabupaten Banyuwangi Jawa Timur seperti suhu, pH, DO dan salinitas masih normal dan mendukung untuk pertumbuhan fitoplankton. Hubungan antara kelimpahan fitoplankton dengan indeks saprobik dari Pearson Correlation sebesar 0,355 artinya bahwa ada hubungan antara kelimpahan fitoplankton dengan indeks saprobik

\section{DAFTAR PUSTAKA}

[1] Setyowidodo I, Santoso BJ. Terhadap Moment Tensor Gempa Bumi Di. 2011;3(2):113-128.

[2] Labupili AG., Dewi IJP, Heriansyah FA. Plankton Sebagai Indikator Pencemaran Perairan Di Kawasan Pelabuhan Yang Dijadikan Tempat Pendaratan Ikan Di Bali. $J$ Kelaut dan Perikan Terap. 2018;1(1):22-29.

[3] Munandar, Marlian N, Wahyudi R. Indeks Keanekaragaman Komunitas Fitoplankton Sebagai Bioindikator Saprobitas Perairan Di Sekitar Pembangkit Listrik Tenaga Uap
(PLTU) Kabupaten Nagan Raya. 2017;4:126-142.

[4] Pransidi IG, Darmadi NM, Arya IW, Gede D, Edi S, Kawan IM. Analisis Status Trofik dan Struktur Saprobik Fitoplankton di Bendungan Telaga Tunjung , Kabupaten Tabanan , Bali. 2020;25(April):64-70.

[5] Fatmayanti N, Apriadi T, Melani WR. Fitoplankton sebagai bioindikator kualitas perairan pada zona litoral waduk Sei Pulai, Pulau Bintan, Kepulauan Riau. Depik J Ilmu-Ilmu Perairan, Pesisir dan Perikan. 2019;8(3):176-184. doi:10.13170/depik.8.3.14144

[6] Kamilah F, Rachmadiarti F, Indah NK. Keanekaragaman Plankton Yang Toleran Terhadap Kondisi Perairan Tercemar. LenteraBio. 2014;3(3):226-231.

[7] Susanti R, Anggoro S, Suprapto D. Kondisi Kualitas Air Waduk Jatibarang Ditinjau Dari Aspek Saprobitas Perairan. J Maquares. 2018;7:121-129. papers2://publication/uuid/512EBCE8D635-4348-A67D-22DD52988F4C.

[8] Wijaya TS, Hariyati R. Struktur Komunitas Fitoplankton sebagai Bio Indikator Kualitas Perairan Danau Rawapening Kabupaten Semarang Jawa Tengah. Strukt Komunitas Fitoplankt sebagai Bio Indik Kualitas Perair Danau Rawapening Kabupaten Semarang Jawa Teng. 2011;19(1):55-61. doi:10.14710/baf.v19i1.2584

[9] Esty Dewi Pratiwi. Hubungan Kelimpahan Plankton Terhadap Kualitas Air Di Perairan Malang Rapat Kabupaten Bintan Provinsi Kepulauan Riau. Kelimpahan Plankt. $2015 ; 1$ https://ci.nii.ac.jp/naid/40021243259/.

[10] Fajar MGN, Siti Rudiyanti, Churun A`in. Pengaruh Unsur Hara Terhadap Kelimpahan Fitoplankton Sebagai Bioindikator Pencemaran. Maqures Manag Aquat Resour. 2016;5:32-37.

[11] Sayekti RW, Yuliani E, Bisri M, et al. Studi evaluasi kualitas dan status trofik air Waduk Selorejo akibat erupsi Gunung Kelud untuk budidaya perikanan. J Tek Pengair. 2015;6(1):133-145.

[12] Marasabessy MD, . E, Valentin L. 
Pemantauan Kadar Logam Berat Dalam Air Laut Dan Sedimen Di Perairan Pulau Bacan, Maluku Utara. MAKARA Sci Ser. 2011;14(1):32-38.

doi:10.7454/mss.v14i1.478

[13] Suwondo, Febrita E, Dessy, Alpiisari M. Kualitas Biologi Perairan Sungai Senapelan, Sago Dan Sail Dikota Pekanbaru Berdasarkan Bioindskator Plankton Dan Bentos. Biogenesis. 2004;1(1):15-20.

[14] Bintal Amin E a. Kandungan Bahan Organik Sedimen dan Kelimpahan Makrozoobenthos sebagai Indikator Pencemaran Perairan Pantai Tanjung 86 Uban Kepulauan Riau. Jurnal Perikanan dan Ilmu Kelautan: Universitas Riau. 2012. Recent Res Sience Technol. 2012;4(10):16-20.

[15] Yazwar. Keanekaragaman Plankton dan Keterkaitannya dengan Kualitas Air di Parpat Danau Toba. Sekol Pascasarj Univ Sumatera Utara M E D a N. 2008.

[16] Rasjid Y. Analisis Keanekaragaman Plankton sebagai Indikator Kualitas Perairan Pantai Batu Gosok Kecamatan Komodo Kabupaten Manggarai Barat Nusa Tenggara Timur. $J$ Bionature. 2017;18(1):44-53.

[17] Pulungan AB, Putra AM, Hamdani H, Hastuti H. Sistem Kendali Kekeruhan dan pH Air Kolam Budidaya Ikan Nila. Elkha. 2020;12(2):99.

doi:10.26418/elkha.v12i2.40688

[18] Gurning LFP, Nuraini RAT, Suryono S. Kelimpahan Fitoplankton Penyebab Harmful Algal Bloom di Perairan Desa Bedono, Demak. J Mar Res. 2020;9(3):251-260.

https://ejournal3.undip.ac.id/index.php/jmr /article/view/27483.

[19] Pratama L, Surbakt H, Agustriani F. Pola Sebaran Salinitas Menggunakan Model Numerik Pattern of Salinity Distribution Using Numerical Models in Bungin River Estuary Banyuasin Regency , South Sumatera. Maspari J. 2018;10(1):9-16.

[20] Sari AN, Hutabarat S, Soedarsono P. Struktur Komunitas Plankton pada Padang Lamun di Pantai pulau Panjang Jepara. J Maquares. 2014;3:82-91. 